ЗАЯКИНА Ольга Александровна - кандидат социологических наук, ведущий специалист по учебно-методической работе, доцент кафедры социологии, психологии и социального менеджмента Московского авиационного института (125993, Россия, г. Москва, Волоколамское ш., 4; zayakinaolga@mail.ru)

\title{
СОЦИАЛЬНО-ЭКОНОМИЧЕСКОЕ САМОЧУВСТВИЕ РОССИЙСКИХ СЕМЕЙ С ДЕТЬМИ В УСЛОВИЯХ ПАНДЕМИИ КОРОНАВИРУСНОЙ ИНФЕКЦИИ
}

\begin{abstract}
Аннотация. Статья посвящена рассмотрению сущности социального самочувствия семьи. Автор указывает, что оно во многом зависит от социально-экономических процессов, происходящих в современном обществе, и связано с социальными гарантиями со стороны государства в конкретный период времени. В статье проводится анализ статистических данных, результатов опросов российских семей с детьми о социальном положении и самочувствии в 2019-2020 гг. Автор отмечает, что за последний год в России наблюдается увеличение уровня тревожности населения по поводу своего материального положения и возможности обеспечить свою семью всем необходимым. Особое внимание в статье уделяется анализу мер государственной поддержки в отношении данной категории населения.
\end{abstract}

Ключевые слова: социально-экономическое самочувствие, семья, несовершеннолетние дети, социальная поддержка, доходы, безработица

$\mathrm{B}$ современных условиях, характеризующихся падением доходов россиян, увеличением уровня безработицы, закрытием определенного числа предприятий из-за пандемии коронавирусной инфекции и вынужденной самоизоляции россиян, особенно важно рассмотреть социально-экономическое самочувствие российских семей с несовершеннолетними детьми.

Термин «социальное самочувствие» широко используется в научной литературе. Социальное самочувствие в справочниках рассматривается как «социально-эмоциональный аспект оценки представителями социальной группы своего общественного положения», а также уровня удовлетворения потребностей и интересов 1 .

Особое внимание ученые уделяют рассмотрению сущности социального самочувствия и факторов, оказывающих влияние на его формирование (Т.И. Заславская, И.С. Кон, Ж.Т. Тощенко, В.А. Ядов и др.). В социологической литературе анализируются критерии социального самочувствия (А.В. Меренков, 3.Т. Голенкова, А.Г. Здравомыслов, И.И. Осинский и др.). Социальное самочувствие рассматривается в связи с оценкой индивидом социальной реальности и своего места в ней (А.С. Балабанов, Т.Б. Бередников, Н.Е. Тихонович, Т.Н. Юдина). Социологи анализируют социальное самочувствие различных социально-демографических групп: молодежи (Л.Н. Баталова, Л.Е. Петрова), студентов (О.А. Лебеденко, Ю.Р. Вишневский), пожилых людей (О.А. Асланова, Т.Е. Быковская), мигрантов (Н.Н. Кобозева, Н.В. Кондрашова), семей с детьми (И.Ф. Дементьева, Т.А. Ишутина, В.Ф. Иванова, Б.С. Павлов) и др.

Социально-экономическое самочувствие семьи можно определить как «социальное ощущение и оценка ‘... семьями уровня гарантированности своего материально-экономического обеспечения» для удовлетворения потребностей

\footnotetext{
1 Российская энциклопедия социальной работы. 2016. М.: ИТК «Дашков и К». С. 691.
} 
[Городская власть... 1998: 11]. В рамках данного подхода особое внимание уделяется именно государственной поддержке населения и социальным гарантиям со стороны государства в конкретный период времени.

Социальное самочувствие семьи во многом зависит от социально-экономических процессов, происходящих в современном обществе. Необходимо отметить, что за последний год в России наблюдается увеличение уровня тревожности населения по поводу своего материального положения и возможности обеспечить свою семью всем необходимым. Это обусловлено объективными причинами: безработица в нашей стране растет, повысились цены на продукты питания. По данным Росстата, уровень безработицы в октябре 2020 г. составил $6,3 \%$ и вырос за полгода на $0,5 \%$, а в ноябре, по итогам выборочного обследования, $-6,1 \%$. Как мы видим, с октября по ноябрь произошло незначительное снижение уровня безработицы ${ }^{1}$.

В Москве за последние восемь-десять месяцев существенно возросло число горожан, которые зарегистрировались в качестве безработных в службах занятости. По словам официального представителя Минтруда столицы Е. Стружака, в Москве число безработных граждан за время эпидемии коронавируса увеличилось в 7 раз, и в ноябре 2020 г. на биржах труда были зарегистрированы более 186 тыс. чел. ${ }^{2}$

Из-за ограничений, связанных с увеличением числа заболевших коронавирусной инфекцией, часть малых и средних предприятий были вынуждены закрыться, другие продолжают работать, но сокращают численность персонала. В сложной ситуации оказываются семьи, в которых есть несовершеннолетние дети, т.к. наличие ребенка всегда требует дополнительных материальных затрат. В некоторых регионах школьники продолжают и сейчас учиться дистанционно, а это предполагает дополнительные затраты на качественный Интернет, покупку компьютера для каждого школьника в семье.

По результатам опросов, проведенных Всероссийским центром изучения общественного мнения, в сентябре 2020 г. около $60 \%$ россиян считали, что тяжелые времена еще впереди. Оптимистов, считающих, что трудные времена позади, стало гораздо меньше. Если в декабре 2019 г. их стало 26\%, то в апреле 2019 г. (во время первой волны пандемии) их было 6\%. Летом и осенью 2020 г. число оптимистов увеличилось до 16-17\%, но эти цифры все равно меньше показателей 2019 г. $^{3}$

Население нашей страны уже научилось приспосабливаться к возникающим трудностям. Поэтому число респондентов, которых все в целом устраивает в их жизни, практически не изменялось (сентябрь 2019 г. и сентябрь 2020 г. - 46\%). Большинство опрошенных россиян квалифицируют свое материальное положение как среднее, причем число респондентов, выбравших данный вариант ответа, за год не изменилось $(60 \%)^{4}$.

Факторами, которые мешают опрошенным россиянам стать счастливыми, по данным ВЦИОМа, являются: 1) материальные трудности; 2) плохое состоя-

\footnotetext{
1 Федеральная служба государственной статистики. Информация о социальноэкономическом положении России - 2020 г. Доступ: https://gks.ru/bgd/free/B20_00/Main. htm (проверено 06.05.2021).

2 Уровень безработицы в Москве увеличился в семь раз. - Глас.ru. 16.11.2020. Доступ: https://glas.ru/economics/66061-uroven-bezraboticy-v-moskve-uvelichilsja-v-sem-raz.html (проверено 06.05.2021).

3 Социальное самочувствие россиян: мониторинг. Опрос ВЦИОМа от 19.10.2020. Доступ: https://old.wciom.ru/index.php?id=236\&uid=10592 (проверено 05.06.2021).

4 Там же.
} 
ние своего здоровья и здоровья близких; 3) безработица и отсутствие стабильности 1 .

Ощущение счастья опрошенные находят в своей семье. Сегодня как никогда повышается важность для населения благополучия в семье и счастливой семейной жизни в целом. Именно успехи детей, счастливые супружеские отношения занимают первые места в системе ценностей россиян.

Меры социальной поддержки российских семей и предприятий, относящихся к наиболее пострадавшим отраслям экономики, в период пандемии позволили несколько сгладить негативные тенденции развития нашей экономики. Российские семьи с детьми получили следующую временную дополнительную помощь:

а) выплата на детей до 3 лет (5 тыс. руб. в месяц на каждого ребенка);

б) выплата на детей от 3 до 16 лет (2 раза по 10 тыс. руб.);

в) доплата на детей к пособию по безработице (3 тыс. руб. на каждого ребенка до 18 лет) [Ключевская 2020].

В декабре 2020 г. в связи с трудной ситуацией президент РФ объявил о новой разовой выплате в 5000 руб. на детей до 7 лет.

Пособие на детей от 3 до 7 лет с июня 2020 г. получают родители в семьях с низкими доходами. Доступны для малообеспеченных семей с маленькими детьми и пособия на ребенка до 3 лет. Продолжает действовать в нашей стране и система материнского капитала, благодаря которой многие семьи улучшили свои жилищные условия или оплатили качественное образование детям. Сейчас сертификат на материнский капитал выдают и на первого ребенка.

Процедура получения пособий на детей стала более удобной, поскольку некоторые пособия и выплаты можно теперь оформить дистанционно за несколько минут. Это экономит время и нервы родителей, им не приходится, как это было еще 10-20 лет назад, обивать пороги госучреждений.

По данным опроса, проведенного социологами ВШЭ в 2020 г., около 40\% граждан получали какие-либо выплаты от государства в связи с пандемией коронавирусной инфекции. При этом в основном это были именно выплаты на детей. К другим мерам социальной поддержки население прибегало гораздо реже, что, очевидно, связано с отсутствием должного уровня информированности россиян.

Как показало исследование, в 2020 г. (по сравнению с 2018 г.) увеличилось число тех, кто считает, что государство должно обеспечить нормальный уровень жизни людям, временно попавшим в трудную жизненную ситуацию (безработным, пострадавшим от стихийных бедствий т.п.), а во всех остальных случаях люди должны обеспечивать себя сами. Если в 2018 г. респондентов, придерживающихся данного мнения, было 27\%, то в 2020 г. - 40\% 2 . Исследования социологов ВШЭ зафиксировали увеличение среди населения нашей страны доли тех, которые верят в свои силы. Если в 2016 г. только 22\% опрошенных считали, что могут изменить свою жизнь к лучшему собственными силами, то в 2020 г. их стало уже $30 \%^{3}$.

В целом, хотелось бы сделать вывод, что российские семьи с детьми адаптировались к новой непростой ситуации. Этому способствовали те меры государственной поддержки, которые были осуществлены и продолжают осу-

\footnotetext{
1 Индекс счастья - 2020. Аналитический обзор. 16.11.2020. Доступ: https://wciom.ru/ analytical-reviews/analiticheskii-obzor/indeks-schastja-2020 (проверено 06.05.2021).

2 Социальное самочувствие россиян: как пандемия меняет общество. Новости экспертизы в НИУ ВШЭ. 07.12.2020. Доступ: https://www.hse.ru/news/expertise/423652975. html (проверено 06.05.2021).

3 Там же.
} 
ществляться. Президент России В.В. Путин, выступая на ежегодной прессконференции, особо отметил, что «выстроена целая программа поддержки семей с детьми» ${ }^{1}$ и принятые оперативные меры помогли сгладить сложившуюся ситуацию. Хотя большинство опрошенных россиян характеризуют свое материальное положение на современном этапе как среднее, больше половины из них считают, что трудные времена еще впереди. Остается надеяться, что адресная государственная поддержка семей с детьми продолжится и станет систематической для семей, оказавшихся в сложной экономической ситуации. На современном этапе требуется также повышение информированности населения обо всех причитающихся постоянных и временных выплатах и формах поддержки.

\title{
Список литературы
}

Городская власть и горожане: прямая и обратная связь. 1998. Екатеринбург: ИЭ УрО РАН. 122 с.

Ключевская Н. 2020. Выплаты на детей в условиях пандемии: кому положены, в каком размере и как их получить. Доступ: https://www.garant.ru/ article/1374516/ (проверено 06.05.2021).

ZAYAKINA Olga Aleksandrovna, Cand.Sci. (Soc.), Leading Specialist in Educational and Methodological Work, Associate Professor of the Chair of Sociology, Psychology and Social Management, Moscow Aviation Institute (4 Volokolamskoe Highway, Moscow, Russia, 125993; zayakinaolga@mail.ru)

\section{SOCIO-ECONOMIC FEELING OF RUSSIAN FAMILIES WITH CHILDREN DURING THE CORONAVIRUS INFECTION PANDEMIC}

\begin{abstract}
The article is devoted to the essence of the social well-being of the family. The author points out that it largely depends on the socio-economic processes taking place in the modern society, and is associated with social guarantees of the state in the specific period.

The author analyzes the statistical data of the survey of Russian families with children on their social status and well-being in 2019-2020 and points out an increase in the level of anxiety of the population about their financial situation and the ability to provide their family with everything they needed. The article pays particular attention to the analysis of government support measures to this category of the population.
\end{abstract}

Keywords: socio-economic well-being, family, minor children, social support, income, unemployment

\footnotetext{
${ }^{1}$ Ежегодная пресс-конференция Владимира Путина. - Президент России. Официальный caŭm. 17 декабря 2020. Доступ: http://kremlin.ru/events/president/news/64671 (проверено 06.05.2021).
} 